\title{
KELESTARIAN LINGKUNGAN SUMBER DAYA ALAM KELAUTAN DALAM IMPLIKASI REKLAMASI LAUT
}

\author{
Maria Francisca M, Ignatius Roberto \\ Universitas Presiden \\ J1. Ki Hajar Dewantara, Cikarang Utara, Bekasi
}

\begin{abstract}
Reclamation is a process of making new land on land that was previously covered by water, such as river banks or coastal coasts. The new area is usually used for residential areas, industry, business, air ports, agriculture, and tourism; in fact this reclamation has a positive and negative impact on the environment and surrounding communities. The Government has provided special arrangements for the spatial plan (RTRW) of each region including the sea, but its implementation is not aligned with more attention to the economic impact than the conservation of its natural resources. The research method used is descriptive analytical and explorative, to obtain an overview of marine policy for the utilization of marine reclamation that still pay attention to the environment and its resources. The reclamation of the sea causes a disruption of the ecosystem that causes many fishermen to lose their livelihood and cause natural disasters in other locations outside the reclamation area
\end{abstract}

\section{Keywords: Reclamation, Marine Resources, Ecosystems}

\begin{abstract}
Abstrak
Reklamasi pada dasarnya adalah proses pembuatan daratan baru di lahan yang tadinya tertutup oleh air, seperti misalnya bantaran sungai atau pesisir pantai. Kawasan baru tersebut biasanya dimanfaatkan untuk kawasan pemukiman, perindustrian, bisnis, pelabuhan udara, pertanian, dan pariwisata, dalam kenyataannya reklamasi ini memiliki dampak positip dan negatif kepada lingkungan hidup dan masyarakat di sekitarnya. Pemerintah telah memberikan pengaturan khusus untuk rencana tata ruang wilayah (RTRW) setiap daerah termasuk lautnya, tetapi pelaksanaanya tidak selaras lebih memperhatikan dampak perekonomian dibandingkan pelestarian sumber daya alamnya. Metode penelitian yang digunakan bersifat deskriptif analitis dan ekploratif, untuk memperoleh gambaran mengenai kebijakan kelautan untuk pemanfaatan reklamasi laut yang tetap memperhatikan lingkungan hidup dan sumber dayanya. Reklamasi laut menyebabkan terganggunya ekosistem yang menyebabkan banyaknya nelayan yang kehilangan mata pencaharian serta menyebabkan bencana alam di lokasi lain di luar daerah reklamasi.
\end{abstract}

\section{Kata Kunci: Reklamasi, Sumber Daya Alam Kelautan, Ekosistem}

\section{A. PENDAhuluan}

Reklamasi pada dasarnya adalah proses pembuatan daratan baru di lahan yang tadinya tertutup oleh air, seperti misalnya bantaran sungai atau pesisir pantai. Kawasan baru tersebut biasanya dimanfaatkan untuk kawasan pemukiman, perindustrian, bisnis, pelabuhan 
udara, pertanian, dan pariwisata. Reklamasi ini biasanya dilakukan oleh negara atau kota yang memiliki laju pertumbuhan dan kebutuhan yang meningkat pesat tapi memiliki keterbatasan lahan. Reklamasi memberikan banyak keuntungan dalam mengembangkan wilayah. Sejumlah hal positif yang bisa didapat dari kegiatan reklamasi ini diantaranya adalah : peningkatan secara signifikan kualitas \& keekonomisan wilayah pantai, pengurangan wilayah yang tidak produktif, pertamnahan daerah dan wilayah hsil reklamasi, perlindungan wilayah pesisir dan pantai dari acaman dan bahaya abrasi, upgrade kualitas ekosistem disekitar pesisir, perbaikan rejim hidraulik di lingkungan pesisir, mampu membuka lapangan pekerjaan baru, serta pengembangan wisata bahari. ${ }^{1}$ Dampak positif yang bisa didaptakan lainnya adalah karena pulau hasil reklamasi mampu menahan terjangan gelombang pasang yang mampu mengikis pantai serta dapat menjadi bendungan untuk menahan banjir air rob di daratan. ${ }^{2}$

Sebagai upaya rekayasa buatan untuk menambah luas wilayah, reklamasi diharapkan mampu meningkatkan daya tampung \& daya dukung lingkungan (environmental carrying capacity) secara menyeluruh. ${ }^{3}$ Reklamasi ini dilakukan dalam rangka meningkatkan manfaat SDA yang ditinjau dari faktor lingkungan \& sosial ekonomi dengan cara pengurukan, pengeringan lahan/drainase. ${ }^{4}$ Hal ini biasanya dijadikan salah satu solusi akibat meningginya angka populasi manusia di wilayah pesisir. Contoh dari kegiatan reklamasi ini adalah reklamasi di wilayah Hong Kong yang digunakan untuk membangun Bandara Internasional Hong Kong; reklamasi di wilayah Singapura untuk memperluas wilayah mereka yang sempit; reklamasi di Palm Island, Dubai yang digunakan sebagai resor mewah; reklamasi di China, sebagai kawasan industri, pelabuhan, kawasan berikat, FTZ, dan pemukiman beserta fasilitasnya; reklamasi di wilayah Song Do, Korea Selatan, yang digunakan untuk membangun Bandara Udara Internasional Incheon, untuk wilayah resor, perkantoran, perhotelan, pemukiman, serta kawasan industri dan FTZ; dan reklamasi di Kansai, Kyoto, Jepang, kegiatan reklamasi di sini dilakukan untuk perluasan pelabuhan laut serta perluasan Bandara Udara Kansai sebagai respons dari pemerintah setempat atas protes masyarakat sekitar yang merasa terganggu dengan bisingnya suara pesawat yang lalu lalang di bandara ini, mengingat bandara ini memiliki tingkat kesibukan yang tinggi.

Secara umum reklamasi dibedakan menjadi dua jenis, yaitu reklamasi yang dilakukan dengan menempel di wilayah pantai secara langsung \& reklamasi yang dilakukan dengan cara memisahkan wilayah reklamasi dari daratan induknya. ${ }^{5}$ Metode reklamasinya sendiri bergantung pada cara atau sistem yang diaplikasikan. Berdasarkan buku Pedoman Reklamasi di Wilayah Pesisir, reklamasi dibagi menjadi empat jenis, yaitu ${ }^{6}$ :

1. Reklamasi Sistem Timbun

\footnotetext{
${ }^{1}$ Seperti dikutip dari laman es.srcibd.com dan oceocean.blogspot.com

${ }^{2}$ Ibid.

${ }^{3}$ Seperti dikutip dari laman nawarsyarif.blogspot.com

${ }^{4}$ Ibid.

${ }^{5}$ Loc. Cit. dari laman es.srcibd.com

${ }^{6}$ Ibid.
} 
Sistem Timbun dapat dilakukan dengan cara menguruk wilayah air disekitar pantai hingga posisi lahan berada di atas posisi air laut tertinggi (high water level),

\section{Reklamasi Sistem Polder}

Reklamasi Sistem Polder dapat dilakukan dengan cara melakukan pengeringan terhadap wilayah perairan yang akan direklamasi. Caranya adalah dengan memompa air yang berada di dalam tanggul kedap air untuk dibuang keluar dari daerah lahan reklamasi,

\section{Reklamasi Sistem Gabungan}

Reklamasi sistem ini merupakan gabungan dari kedua metode di atas. Pertama lahan yang akan direklamasi dikeringkan terlebih dahulu melalui cara dipompa, setelah itu wilayah yang sudah tidak digenangi air, diuruk dengan tanah hingga menyerupai daratan.

4. Reklamasi Sistem Pengeringan

Reklamasi sistem penegringan dilakukan dengan cara mengeringkan wilayah pesisir hingga nampak daratan saja, lazim ditemui didaerah dataran dimana muka air pesisir tidak begitu rendah atau tak terlalu tinggi disbanding wilayah daratnya.

Metode timbun relative lebih pas jika diterapkan pada wilayah bercurah hujan tinggi alias wilayah tropis. Sementara reklamasi dengan sistem polder lebih pas jika diterapkan pada wilayah dengan sistem drainase yang baik. Oleh karena itu, sistem reklamasi timbun merupakan sistem reklamasi yang paling populer di Indonesia.

Namun, kegiatan reklamasi ini tidak hanya memberikan dampak positif dalam pelaksanaannya, tetapi juga memberikan dampak negatif. Dampak negatif yang bisa timbul meliputi dampak fisik, seperti perubahan hidro-oceanografi, erosi pantai, sedimentasi, peningkatan kekeruhan, pencemaran laut, perubahan rejin air tanah, peningkatan potensi banjir \& penggengangan di wilayah pesisir. ${ }^{7}$ Akibat secara biologis juga bisa timbul, seperti terganggunya ekosistem mangrove, terumbu karang, padang lamun, estuaria dan penurunan keanekaragaman hayati biota laut, baik flora maupun fauna, karena timbunan tanah urukan akan mempengaruhi ekosistem yang sudah ada, lalu sistem hidrologi gelombang air laut yang jatuh ke pantai akan berubah dari alaminya. ${ }^{8}$

Berubahnya alur air akan mengakibatkan daerah di luar reklamasi mendapat limpahan air yang banyak sehingga memungkinkan terjadinya abrasi, atau mengakibatkan terjadinya banjir rob. ${ }^{9}$ Lalu aspek lain yang perlu diperhatikan adalah aspek sosial ekonomi. Efek dari dampak-dampak yang disebutkan sebelumnya akan meluas dan mempengaruhi kehidupan dari masyarakat sekitar. Banyak nelayan dan pekerja di sektor perikanan yang akan kehilangan mata pencahariannya akibat merosotnya jumlah ikan akibat rusaknya ekosistem. Di beberapa wilayah yang di reklamasi, arus ombaknya berubah sehingga mengakibatkan turunnya minat wisatawan yang ingin melakukan kegiatan selancar.

\footnotetext{
${ }^{7}$ Dikutip dari laman repository.uinjkt.ac.id

${ }^{8}$ Ibid.

${ }^{9}$ Ibid.
} 
Di Indonesia sendiri, sedang terjadi perdebatan mengenai pro dan kontra dari kegiatan reklamasi yang akan dilakukan di wilayah Teluk Benoa, Bali. Selain perdebatan mengenai pro dan kontra, kegiatan reklamasi ini juga diduga ada penyelewengan hukum akibat diubahnya status wilayah Teluk Benoa dari kawasan konservasi (ditegaskan melalui Pasal 93 Peraturan Presiden 45 Tahun 2011 Tentang Rencana Tata Ruang Kawasan Perkotaan Sarbagita) menjadi kawasan pemanfaatan umum (melalui Peraturan Presiden 51 Tahun2014) dan diijinkan untuk melakukan kegiatan reklamasi seluas maksimal 700 hektar. Oleh karena itu penulis merasa tertarik untuk meneliti mengenai permasalahan ini, mengingat kegiatan reklamasi ini berkaitan dengan kehidupan orang banyak dan juga berdampak luas bagi kehidupan masyarakat di Bali.

\section{B. PEMBAHASAN}

Dalam pengembangkan suatu kebijakan kelautan (ocean policy), maka diperlukan persyaratan yang harus dipenuhi yaitu, pertama, kebijakan tersebut harus memiliki instrument yang efektif untuk menjalankannya (policy tools). Instrumen tersebut sebaiknya (i) dapat diaplikasikan (applicability) secara leluasa (discretionary) dan universal serta dapat ditegakkan secara hukum (enforceability); dan (ii) memiliki kewenangan administratif (right of administrative authorities) yang mencakup aspek insentif dan regulatif. Kedua, kebijakan tersebut dapat memberikan dampak terhadap perekonomian domestik maupun global. Artinya kebijakan itu mendapatkan dukungan/konsesus secara nasional (khususnya di level pemerintah dan legislatif) maupun internasional. Ketiga, kebijakan tersebut harus efisien dan efektif atau cost effective secara ekonomi dan adil (fairness), sehingga mampu mendorong pertumbuhan dan pemerataan kesejahteraan rakyat. Keempat, kebijakan harus mampu mendorong kemandirian rakyat dan berlandaskan nilai-nilai luhur agama dan moralitas.

Kebijakan laut ini juga berperan penting dalam reklamasi laut yang seharusnya pelaksanaan reklamasi laut ini terdapat sebuah kewajiban dari pemerintah. Pemerintah seharusnya memberikan perlindungan hukum dalam rangka pembangunan wilayah maritim yang meliputi: pengelolaan Sumber Daya Kelautan; pengembangan SDM, pertahanan, keamanan, penegakan hukum, dan keselamatan di laut; peningkatan kesejahteraan; ekonomi kelautan dan pengelolaan ruang laut. ${ }^{10}$

Kebijakan tersebut pada dasarnya telah tercantum dalam Rencana Umum Kelautan Nasional (RUKN), yang memuat substansi fundamental dan strategis (dalam jangka waktu pendek, menengah dan panjang). ${ }^{11}$ RUKN berfungsi sebagai ${ }^{12}$ :

1. Acuan dan pedoman bagi Kementerian/Lembaga (K/L) dalam menyusun perencanaan pengelolaan kelautan.

2. Acuan dan pedoman penyusunan Rencana Kerja $\mathrm{K} / \mathrm{L}$ terkait dengan pengelolaan kelautan.

3. Pedoman dalam melakukan koordinasi perencanaan umum kelautan antar sektor, antar instansi terkait di pusat dan daerah.

\footnotetext{
${ }^{10}$ Dikutip dari laman setkab.go.id

${ }^{11}$ Ibid.

${ }^{12}$ Ibid.
} 
4. Pengendalian kegiatan pembangunan nasional sektor kelautan.

5. Acuan bagi Kementerian Koordinator Bidang Kemaritiman dan Kementerian PPN/Bappenas untuk melakukan pengawasan pelaksanaan kebijakan di bidang kelautan yang bersifat lintas sektoral.

Kebijaksanaan di bidang laut ini seharusnya juga dapat memberikan perlindungan hukum pada kelestarian lingkungan dan wilayah daerah sekitarnya, karena apabila tidak diawasi menimbulkan kerusakan yang sangat besar untuk ekosistem laut. Reklamasi ini tidak saja berhubungan dengan hukum lingkungan tetapi termasuk juga tata ruang wilayah. kegiatan reklamasi ini tidak hanya memberikan dampak positif dalam pelaksanaannya, tetapi juga memberikan dampak negative sebagaimana yang telah penulis jelaskan di bagian pendahuluan.

Aspek lain yang perlu diperhatikan adalah aspek sosial ekonomi. Efek dari dampakdampak yang disebutkan sebelumnya akan meluas dan mempengaruhi kehidupan dari masyarakat sekitar. Banyak nelayan dan pekerja di sektor perikanan yang akan kehilangan mata pencahariannya akibat merosotnya jumlah ikan akibat rusaknya ekosistem karena limpasan sedimen. Di beberapa wilayah yang di reklamasi, arus ombaknya berubah sehingga mengakibatkan turunnya minat wisatawan yang ingin melakukan kegiatan selancar. Juga potensi dari wilayah hasil reklamasi yang menjadi tempat ekslusif dan bersifat komersil bagi kalangan tertentu saja. Pada awalnya tujuan dari program reklamasi ${ }^{13}$ yaitu :

1. Untuk mendapatkan kembali tanah yang hilang akibat gelombang laut

2. Untuk memperoleh tanah baru di kawasan depan garis pantai untuk mendirikan bangunan yang akan difungsikan sebagai benteng perlindungan garis pantai

3. Untuk alasan ekonomis, pembangunan atau untuk mendirikan konstruksi bangunan dalam skala yang lebih besar.

Tindakan reklamasi merupakan kegiatan berskala besar yang harus dilakukan secara hati-hati dan teliti. Karena reklamasi ini memiliki dampak terhadap berbagai faktor seperti lingkungan, ekonomi, sosial budaya; seperti yang sudah disebutkan sebelumnya di atas. Untuk itu diperlukan proses perizinan yang panjang dan kajian yang komprehensif sebelum kegiatan reklamasi dilakukan agar kegiatan reklamasi dapat dilaksanakan dan tidak berdampak buruk bagi lingkungan sekitarnya. Dalam pelaksanaan dari reklamasi ini perlu membuat visibility study yang mencantumkan mengenai ${ }^{14}$ :

1. Pengendalian dampak negatif lingkungan dari campur tangan manusia terhadap alam akan berimbas kepada ekosistem yang ada di laut sebelumnya, maka perlu dilakukannya pencegahan dampak meluas akibat reklamasi ini. ${ }^{15}$

2. Suplai air dan energi dibutuhkan di daerah pengembangan termasuk juga di daerah rekalamasi, dari sini perencana harus memperhitungkan betul dari mana sumber energy dan listrik. ${ }^{16}$

\footnotetext{
${ }^{13}$ max wagiu, 2011

${ }^{14}$ Indonesia Water Institute, 2012

${ }^{15}$ Loc. Cit. nawarsyarif.blogspot.com

16 Ibid.
} 
3. Transportasi yang terintegrasi merupakan bagian terpenting bagi pengembangan daerah yang akan berdampak pada arus transportasi di daerah akan meningkat, maka daerah utama \& daerah reklamasi harus diperhitungkan arus transportasi agar menghindari kemacetan karena tidak adanya integrasi dari daerah reklamasi dan daerah utama (daerah asli). ${ }^{17}$

4. Tata ruang \& wilayah. Lahan hasil reklamasi akan digunakan sesuai kebutuhan, sehingga master plan tata ruang dan wilayah harus benar- benar dikerjakan dan diawasi pelaksanaannya. Hal ini menghindari penyebaran daerah kumuh / tak tertata dari sebuah kawasan. ${ }^{18}$

5. Struktur lapisan tanah reklamasi. Hal ini merupakan syarat utama dari ketahanan struktur. Kekuatan lahan reklamasi terhadap abrasi dan beban bangunan diatasnya harus diperhitungkan agar tidak terjadi kerugian yang besar. ${ }^{19}$

Di Indonesia sebagai daerah maritim yang dikeliling laut, dalam upaya melakukan reklamasi, maka kita wajib berpedoman pada beragam produk hukum, meliputi :

1. Permen PU Nomor 4/PRT/M/2007 tentang faktor-faktor yang harus diperhatikan dalam tahapan-tahapan pelaksanaan kegiatan reklamasi, yaitu aspek fisik, ekologi, sosial ekonomi dan budaya, tata lingkungan dan hukum, aspek kelayakan, perencanaan dan metode yang digunakan. ${ }^{20}$

2. UU No. 23 Th 2014 Tentang Pemerintahan Daerah. ${ }^{21}$

3. UU No 32 Th 2009 Tentang Pengelolaan Lingkungan Hidup. ${ }^{22}$

4. UU No. 26 Th 2007 Tentang Penataan Ruang, ${ }^{23}$

5. UU No. 27 Th 2007 Tentang Pengelolaan Wilayah Pesisir dan Pulau-Pulau Kecil. $^{24}$

6. UU No. 24 Th 2007 Tentang Penanggulangan Bencana. ${ }^{25}$

Tindakan penimbunan laut oleh tanah ini secara langsung akan membunuh ekosistem/sumber daya alam ditempat laut itu ditimbun, merusak tatanan ekosistem flora dan fauna, sehingga dapat menimbulkan ketimpangan diantaranya kurangnya supplies makanan untuk spesies tertentu atau hilangnya satu rantai makanan karena menghilangnya ekosistem ditempat yang ditimbun

Oleh karena itu, ketika melakukan reklamasi pantai, perlu diperhatikan beragam aspek yang akan ditimbulkan oleh kegiatan tersebut. ${ }^{26}$ Aspek tersebut diantaranya lingkungan, sosial budaya serta ekonomi. Lingkungan tercemar dan terdampak reklamasi itu sebuah keniscayaan. Kehidupan sosial budaya juga bisa terancam akibat hilangnya ruang terbuka

${ }^{17}$ Ibid.
${ }_{18}$ Ibid.
${ }^{19}$ Ibid.
${ }^{20}$ Ibid.
${ }^{21}$ Ibid.
${ }^{22}$ Ibid.
${ }^{23}$ Ibid.
${ }^{24}$ Ibid.
${ }^{25}$ Ibid.
${ }^{26}$ Ibid. 
yang secara alami elah dinikmati oelh masyarakat di wilayah pesisir. Terlebih segi ekonomi, masyarakat nelayan akan kehilangan mata pencaharian akibat proyek reklamasi ini. Mau makan apa mereka. apakah makan pasir hasil reklamasi. Tentu tidak dan ini sangatlah ironi.

Hasil kajian literaur yang dilakukan oleh penulis menukan, akibat lain reklamasi disekitar wilayah pantai diantaranya :

1. Berkurangnya wilayah pantai untuk kegiatan masyarakat karena akan dimanfaatkan kegiatan privat mereka yang melakukan rekalamasi. Hasil urukan juka akan emmbuat matinya ekosistem dan habitat yang ada. ${ }^{27}$

2. Sistem hidrologi gelombang air laut akan terganggu. ${ }^{28}$ Berubahnya alur air akan berakibat cukup signifikan pada daerah yang berada diluar reklamasi. Daerah diluar reklamasi secara tidak langsung pasti akan mendapat limpahan air yang cukup banyak sehingga sangat memungkinkan timbulnya bencana lain seperti abrasi, tergerus atau banjir/rob. ${ }^{29}$

3. Berdampak sangat besar dan siginifikan terhadap masyarakat pesisir yang mayoritas didominasi oleh kalangan menengah ke bawah, misalnya petambak, nelayan atau buruh. ${ }^{30}$ Aktifitas pengurukan dan reklamasi dapat mengurangi pendapatan nelayan dan rekan-rekan. Karena ikan yang didapat akan berkurang akibat aktifitas reklamasi.

4. Aspek ekologi, dimana pantai merupakan wilayah penyangga daratan dengan beragam biota yang ada disana. Wilayah ekosistem dan habitat disekitar pantai sangat rawan terhadap perubahan. Jadi ketika ada reklamasi, habitat dan ekologi disana pasti akan berubah drastic dan akan mengancam biota yang ada, termasuk mansuia yang didaratan.

Akibat terbesar dari kegiatan ini adalah lingkungan. Kerusakan lingkungan bisa dipastikan akan terjadi, tak hanya ketika proyek reklamasi telah usai, namun saat baru akan direncanakan saja, proyek reklamasi sudah bisa emmakan banyak korban. Misalnya secara tinjauan sosiologis, yang akan mengancam jiwa para nelayan disekitar pesisir. Persiapan proyek reklamasi yang akan mendatangkan alat-alat berat juga mencemari udara di sekitarnya, sehingga lagi-lagi nelayan dan masyarakat disekitar proyek terdampak reklamasi harus menerima kenyataan pahit terpapar polusi,

Pengaturan mengenai lingkungan sendiri telah di atur dalam UU No. 32 Th 2009 Tentang Pengelolaan Lingkungan Hidup. ${ }^{31}$ Undang-undang ini menjamin dalam pelaksanaan pembangunan diharapkan adanya keselarasan hubungan antara manusia dengan manusia, manusia dengan lingkungan dan komponen lingkungan lainnya, serta dapat memenuhi masa kini dan menjaga kelestarian untuk masa datang. ${ }^{32}$ Dampak lingkungan hidup yang sudah jelas nampak di depan mata akibat proyek reklamasi itu adalah kehancuran ekosistem

\footnotetext{
27 Ibid.

${ }^{28}$ Ibid.

${ }^{29}$ Ibid.

${ }^{30}$ Ibid.

${ }^{31}$ Ibid.

${ }^{32}$ Ibid.
} 
berupa hilangnya keanekaragaman hayati. ${ }^{33}$ Keanekaragaman hayati yang diperkirakan akan punah akibat proyek reklamasi itu antara lain berupa hilangnya berbagai spesies mangrove, punahnya spesies ikan, kerang, kepiting, burung dan berbagai keanekaragaman hayati lainnya. $^{34}$

Akibat lain dari proyek ini adalah meningkatkan potensi banjir. ${ }^{35}$ Hal itu dikarenakan proyek tersebut dapat mengubah bentang alam (geomorfologi) dan aliran air (hidrologi) di kawasan reklamasi tersebut. ${ }^{36}$ Perubahan itu antara lain berupa tingkat kelandaian, komposisi sedimen sungai, pola pasang surut, pola arus laut sepanjang pantai dan merusak kawasan tata air. ${ }^{37}$ Potensi banjir akibat proyek ini akan semakin meningkat jika dikaitkan dengan adanya kenaikan muka air laut yang disebabkan oleh global warming, ${ }^{38}$ sehingga akibat yang ditimbulkan oleh proyek ini terhadap ekosistem dan sumber daya alam adalah sangat merusak walaupun dari segi lain dapat berdampak baik.

Alhasil, perlu kiranya pemerintah sebagai pembuat kebijakan, memahami dengan betul jika ada rencana ingin melakukan reklamasi wilayah pesisir seperti yang akhir-akhir ini ingin dilakukan di Teluk Jakarta maupun Teluk Benoa, Bali. Ketikapahaman pemangku kebijakan bisa berdampak pada kerusakan lingkungan, yang tentunya tak hanya berimbas pada kelestarian hidup masyarakat di wilayah pesisir, tapi juga mengancam ekosistem dan habitat biota laut dan sejenisnya. Sehingga evaluasi kebijakan terkait reklamasi perlu segera dilakukan. LSM dan masyarakat pemerhati lingkungan juga diharapkan iku ambil bagian dalam upaya penyelamatan lingkungan ini.

C.

\section{ENUTUP}

Berdasarkan penjabaran tersebut dampak negatif atau kerugian reklamasi pesisir pantai terhadap sumber daya alam kelautan adalah :

1. Peninggian muka air laut karena area yang sebelumnya berfungsi sebagai kolam telah berubah menjadi daratan yang berakibat pada banjir/ erosi di tempat sekitar daerah reklamasi.

2. Akibat peninggian muka air laut maka daerah pantai lainya rawan tenggelam, atau setidaknya air asin laut naik ke daratan sehingga tanaman banyak yang mati, area persawahan sudah tidak bisa digunakan untuk bercocok tanam, hal ini banyak terjadi diwilayah pedesaan pinggir pantai.

3. Musnahnya tempat hidup hewan dan tumbuhan pantai sehingga keseimbangan ekosistem alam menjadi terganggu, apabila gangguan dilakukan dalam jumlah besar maka dapat mempengaruhi perubahan cuaca serta kerusakan planet bumi secara total.

\footnotetext{
${ }^{33}$ Ibid.

${ }^{34}$ Ibid.

${ }^{35}$ Ibid.

36 Ibid.

${ }^{37}$ Ibid.

38 Ibid.
} 
4. Pencemaran laut akibat kagiatan di area reklamasi dapat menyebabkan ikan mati sehingga nelayan kehilangan lapangan pekerjaan.

\section{DAFTAR PUSTAKA}

\section{Buku}

Herry J, 2005, Reklamasi Pantai Dan Pengaruhnya Terhadap Lingkungan Fisik Di Wilayah Kepesisiran Kota Ternate, Tesis Ilmu Lingkungan (Magister Pengelolaan Lingkunga Universitas Gadjah Mada.

International Seminar, On Building a Comprehensive Maritime Security InSoutheast AsiaRegion.

Kusnul Nur Kasanah, Tanpa Tahun, Kepala Subbidang Pendayagunaan Pesisir dan Pulau-Pulau Kecil dan Tata Ruang Kedeputian Bidang Kemaritiman.

Maskur A, 2008, Rekonstruksi Pengaturan Hukum Reklamasi Pantai Di Kota Semarang, Tesis Program Magister Ilmu Hukum Program Pascasarjana Universitas Diponegoro Semarang

Woinarski 2002, Pulau Serangan: Dampak Pembangunan pada Lingkungan dan Masyarakat, Laporan Studi Lapangan, Universitas Muhammadiyah Malang Kerja Sama Dengan Australian Consortium For In-Country Indonesian Studies.

\section{Internet}

http://www.marzukialie.com/?show=tulisan\&id=60

http//www.lautkita.org/reklamasiabrasi_ind.html http://green.kompasiana.com/penghijauan/2010/10/22/arogansi-pemkab-tangerangdalam-reklamasi-pantai\%E2\%80\%A6-298584.html http://kampus.okezone.com/read/2010/11/23/373/396124/reklamasi-pantai-janganlupakan-aspek-sosial

http://kopel-online.or.id 2012 http://manado.tribunnews.com/2011/02/27/dampak-reklamasi-pantai-bagi-masyarakat http://nawarsyarif.blogspot.co.id/2015/08/dampak-reklamasi-pantai-terhadap.html http://setkab.go.id/44348/Oleh: Humas ; Diposkan pada: 6 Jan 2016 http://www.antarasulsel.com DPRD Ancam Hentikan Proyek Reklamasi Pantai $\begin{array}{llll}\text { Mamuju, } & \text { Senin, } & 27 & \text { September }\end{array}$ http://www.esp2indonesia.org/sites/default/files/publications/REA\%20Jakarta\%20Bay_ 
Indonesia_editedJuli11_final\%20(1).pdf.

http://www.fkpmaritim.org/kebijakan-kelautan-indonesia-dalam-kerangka-kerjasama-

keamanan-maritim-asean/

http://www.ilmusipil.com/analisa-dampak-reklamasi-pada-daerah-pesisir-pantai 07 Mei

2013, 13:56:05

http://www.indonesiawaterinstitute.org/reklamasi, 19 December 2012 05:33

http://www.ptbas.co.id/newsdefa2.htm

\section{Peraturan Perundang-undangan}

Undang-Undang Nomor 32 Tahun 2009 Tentang Pengelolaan Lingkungan Hidup

Undang-Undang Nomor 23 Tahun 2014 Tentang Pemerintahan Daerah

Undang-Undang Nomor 24 Tahun 2007 Tentang Penanggulangan Bencana.

Undang-Undang Nomor 27 Tahun 2007 Tentang Pengelolaan Wilayah Pesisir dan Pulau-Pulau Kecil

Peraturan Menteri PU No. 40/PRT/M Tahun 2007 - BKPRN 